\title{
Improvement in embryo quality and pregnancy rates by using autologous cumulus body during icsi cycles
}

\author{
Icsı sikluslarında otolog kumulus kitlesi kullanımı ile embriyo kalitesinde ve gebelik \\ oranlarinda artis
}

\author{
Tahsin Murad Aktan ${ }^{1}$, Hüseyin Görkemli², Kazım Gezginç², Aslı Saylan', Selçuk Duman ${ }^{1}$, Fatma Yazıcı Yılmaz ${ }^{2}$ \\ ${ }^{\prime}$ Department of Histology and Embryology, Meram Faculty of Medicine, Selcuk University, Konya, Turkey \\ ${ }^{2}$ Department of Obstetrics and Gynecology, Meram Faculty of Medicine, Selçuk University, Konya, Turkey
}

\section{Abstract}

Objective: To determine whether the addition of intact cumulus cell mass (ICM) to both embryo culture (EC) and embryo transfer (ET) improves embryo quality and pregnancy rates.

Material and Methods: A total of 133 infertile couples were included, of which 67 received ICM (study group) and 66 did not (control group). The ICM was obtained from a simple cutting of the cumulus corona oocyte complex (CCOC). A case control study design was used.

Results: The clinical characteristics of the two groups before the embryo culturing step were similar with respect to age, estradiol level on the day of hCG and endometrial thickness on the day of embryo transfer $(\mathrm{p}>0.05)$. On the other hand study group with ICM had higher number of high quality embryos ( $3.1 \pm 1.4$ vs $2.4 \pm 1.1, \mathrm{p}=0.03)$, higher implantation rate $(53.7 \%$ vs $34.8 \%, \mathrm{p}=0.02)$ and higher ultrasound confirmation of gestational sac and fetal heart beat as ongoing pregnancy rates $(44.7 \%$ vs $27.2 \%, p=0.04)$ compared to the control group without ICM.

Conclusion: Addition of ICM improves embryo quality and pregnancy rates. This is a cost-and time-effective simple procedure that shows great promise for the improvement of infertility treatment.

(J Turkish-German Gynecol Assoc 2011; 12: 162-7)

Key words: Autologous Cumulus Body, ICSI Cycles, Embryo Quality, Pregnancy Rates

Received: 3 July, 2011

Accepted: 7 August, 2011
Özet

Amaç: Bütünlüğü bozulmamış kumulus hücre kitlesi (BBKHK) hem embriyo kültürüne hem de embriyo transfer aşamalarında kullanımının gelişen embriyonun kalitesine ve gebelik oranlarına bir katkı sağlayıp sağlamadığını araştırmak.

Gereç ve Yöntemler: Çalışmaya kısırlık sorunu ile başvuran ve ICSI işlemine alınan toplam 133 çift dahil edildi, 67 tanesine BBKHK ilavesi yapıldı (çalışma grubu) ve 66 tanesine standart tedavi yapıldı (kontrol grubu). İşlemde kullanılan BBKHK'nın elde edilmesi için sadece kumulus korona oosit kompleksinden basit bir kesme işlemi yapıldı. Çalışma kontrollü olgu şeklinde dizayn edildi.

Bulgular: Çalışmaya dahil edilen her iki grubun yaş, östrodiol seviyeleri ve transfer günü endometrium kalınlığı özellikleri aynı idi ( $\mathrm{p}>0.05)$. Çalışma grubu kontrol grubu ile karşılaştırıldığında embriyo kalitesi ( $3.1 \pm 1.4$ vs $2.4 \pm 1.1, \mathrm{p}=0.03)$, implantasyon oranları $(53.7 \%$ vs $34.8 \%, \mathrm{p}=0.02$ ) ve kalp atımı ultrasound teyidi ile devam eden gebelik oranlarında (44.7\% vs $27.2 \%, \mathrm{p}=0.04$ ) anlamlı farklılıklar ortaya çıktı.

Sonuçlar: Embriyo kalitesi ve gebelik oranları BBKHK ilavesi ile arttırlabilir. Bu işlem zaman ve maddi maliyet artışı getirmeden sadece basit bir girişim ile kısırlık tedavisine önemli katkıda bulunmaktadır.

(J Turkish-German Gynecol Assoc 2011; 12: 162-7)

Anahtar kelimeler: Otolog cumulus kitlesi, ICSI siklusu, Embriyo kalitesi, Gebelik Oranları

Geliş Tarihi: 03 Temmuz 2011

Kabul Tarihi: 07 Ağustos 2011

\section{Introduction}

Assisted-reproduction laboratory protocols are based on the use of parental gametes to develop an embryo and achieve pregnancy. The clinical application of assisted-reproduction technologies began with the birth of the first successful test-tube baby achieved by Robert Edwards in 1978. Since then, extensive research aimed at improving assistedreproduction technologies has been performed to obtain higher conception rates. In addition to the development and improvement of clinical techniques, new techniques for hormone induction and embryo culture and manipulation are continuously being developed in the laboratory. Culture media development is aimed at supporting embryo development. Culture media are designed to mimic the biochemis-

try of human tubal fluid, and their development is limited by the spectrum of current technology. Technological progress in physical and chemical sciences may redefine the analyses of oviduct fluid composition, which may change our knowledge of the interaction of the embryo with the tubal and uterine tissues and enable the emergence of new concepts $(1,2)$. However, this knowledge will always be limited by the spectrum of analytical technologies.

In the present study, we compared the development and implantation of embryos and pregnancy rates between embryos developed in a co-culture system and transferred with cumulus mass addition and those not developed in a co-culture system and transferred without cumulus mass addition. In total,1232 embryos (625 embryos in the study group and 607 control embryos) were evaluated. 


\section{Materials and Methods}

Couples were informed about the study and those who volunteered were included in the study. Our study performed using autologous materials was approved by the Faculty Ethical Committee. Patients selected using the first set of exclusion criteria were further separated into groups according to the order of their inclusion in the study. The first set of exclusion criteria included an anovulatory cycle, sperm obtained by biopsy, and endometriosis (unpredicted). The second set of exclusion criteria eliminated a certain number of patients, and the numbers were compensated by inclusion of more patients from the waiting list. Exclusion using the second set of criteria was performed during the stage after oocyte pickup and progress of the co-culture, and it included ovarian hyperstimulation syndrome (ET was abandoned), unpredicted severe sperm problems, unsuccessful erythrocyte removal from cumulus mass, and other problems such as fertilisation failure or cleavage failures resulting in unsuccessful development of embryos.
Of the 192 couples who were initially included in this case control study, 15 were eliminated after applying the first set of exclusion criteria; thus, of the 177 couples included for the oocyte pickup and co-culturing stage, examination for the second set of exclusion criteria disqualified 31 couples from the study. Finally, 133 couples completed this case control study, as shown in Figure 1.

After ovarian stimulation, oocyte pickup was performed (3), follicular fluid samples were inspected, and CCOCs were collected using a stereomicroscope and placed in human tubal fluid (HTF) (Quinn's Advantage ${ }^{\mathrm{TM}}$ Protein Plus Fertilization HTF Medium, SAGE ${ }^{\circledR}$; CooperSurgical Company, USA). CCOCs were rinsed in HTF, those belonging to group 1 were collected in a different HTF pool $(300 \mu \mathrm{L})$, and an intact cumulus mass (ICM) was separated from the CCOC using insulin injector needles under the stereomicroscope. The separated ICMs were collected in cleavage medium (Quinn's Advantage, Cleavage Medium; $\mathrm{SAGE}^{\circledR}$; CooperSurgical Company, USA). After ICSI, 2-3 oocytes were placed in a droplet $(80-90 \mu \mathrm{L})$ containing $1 \mathrm{ICM}$. Pronucleus control was performed at $18-22$ hours after injection. Oocytes were placed on a new droplet with the same ICM. When incu-

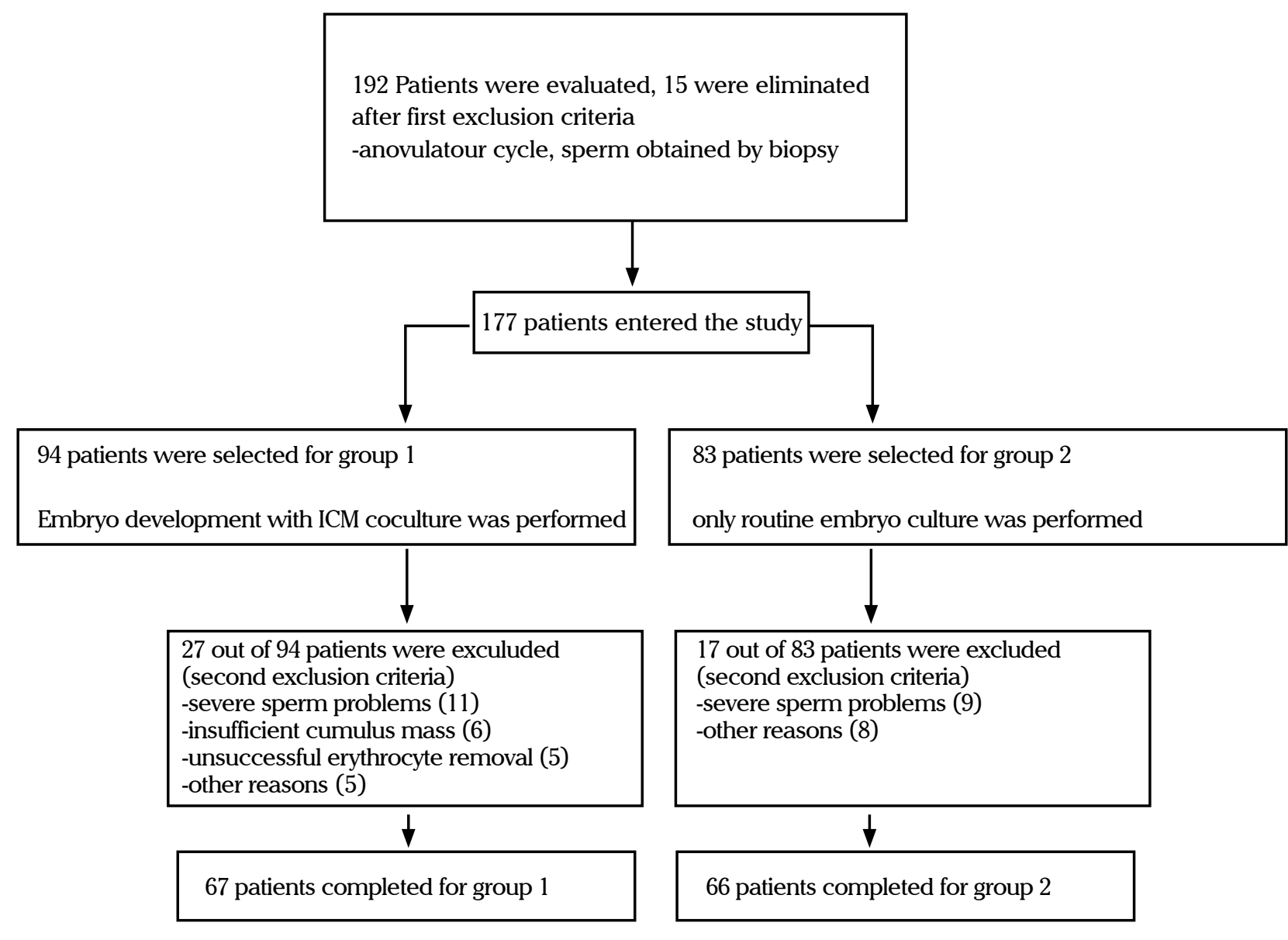

Figure 1. Patient flow chart. The first set of exclusion criteria was applied before the oocyte pickup (OPU) stage, and the second set of exclusion criteria, after OPU. The most frequent 'other reasons' for second exclusion were ovarian hyperstimulation syndrome, which indicated delay of embryo transfer. Remaining reasons included fertilisation failue or cleavage arrest. Abbreviation, ICM: Intact Cumulus Mass 
bation was extended for 3,4 , or 5 days, oocytes were placed in a blastocyst medium (Quinn's Advantage, Blastocyst Medium SAGE$^{\circledR}$; CooperSurgical Company, USA) on the morning of day 3.

\section{Embryo Loading Procedure}

For group 1, cultured embryos that were ready for transfer to the uterus were loaded onto the catheter together with the ICM. In cases in which a cumulus mass was embedded with more than the desired number of embryos, separation was performed with the help of insulin injector needles under the stereomicroscope. Although no standard amount of cumulus mass was used, it was generally 10-15 times larger than the transfer embryo mass.

Samples of group 2 were not treated with the addition of cumulus mass and were subjected to routine embryo loading.

\section{Embryo Grading}

Embryo grading was performed according to the criteria of Veeck (4), with minor modifications due to development dates

Table 1. Expected blastomere number/characteristics according to days. Modifications were introduced when blastomere number was lower than expected on the observation date; a number was subtracted from quality estimation (such as minus 1 or minus 2) as a missed blastomere number

\begin{tabular}{|l|c|}
\hline Observation day & Blastomere number/status \\
\hline 1 & $0-2$ \\
\hline 2 & $2-4$ \\
\hline 3 & $4-8$ \\
\hline 4 & 8-Precompact \\
\hline 5 & Precompact-Hatched \\
\hline
\end{tabular}

and Grade 1 representing the best morphology, so that Grade 1: Embryo with blastomeres of equal size; no cytoplasmic fragments, Grade 2: Embryo with blastomeres of equal size; minor cytoplasmic fragments or blebs, Grade 3: Embryo with blastomeres of distinctly unequal size; no cytoplasmic fragmentation, Grade 4: Embryo with blastomeres of equal or unequal size; major cytoplasmic fragments and numerous blebs and Grade 5: Embryo with few or no recognizable blastomeres; major cytoplasmic fragmentation.

Embryos were also evaluated for the numbers of blastomeres on the basis of the timing of the evaluation, as shown in Table 1, where a grade of 5 represents the highest quality and 1 represents the lowest quality.

The percentage of high quality embryos was calculated according to the number of retrieved metaphase 2 (MII) oocytes per patient (for example, if 8 MII oocytes were retrieved from a patient and only 2 of them reached a high grade form just before embryo transfer, the percentage of high quality embryos was $25 \%$ ).

Statistical analysis of continuous variables of patient and oocyte characteristics was performed using independent sample T-tests. Implantation rates and positive embriyo cardiac activity confirmed via ultrasound were compared using Pearson chisquare analyses. Statistical significance was determined by a probability (p) value less than 0.05 .

\section{Results}

The characteristics of the patients and collected oocytes are described in Tables 2 and 3, respectively. The data show similar characteristics among control and study groups with respect to evaluation of infertility treatment and properties of the collected oocyte.

Table 2. Details of patient characteristics (NS: Non-Significant)

\begin{tabular}{|l|c|c|c|c|}
\hline Characteristic & $\begin{array}{c}\text { G1 } \\
\text { With Cumulus }\end{array}$ & $\begin{array}{c}\text { G2 } \\
\text { Without Cumulus }\end{array}$ & P Value & Significance \\
\hline Number of Patients & 67 & 66 & & \\
\hline Age & $32.8(5.2)$ & $31.4(5.1)$ & 0.128 & NS \\
\hline Thickness of endometrium & & & & NS \\
\hline During transfer (mm) & $10.8(1.8)$ & $11.1(1.6)$ & 0.347 & NS \\
\hline $\begin{array}{l}\text { Estradiol level during hCG } \\
\text { administration (pg/mL) }\end{array}$ & $1725.8(580.6)$ & $1855.9(646.7)$ & 0.224 & NS \\
\hline FSH Admin. & $1.9560(508)$ & $1.9182(423)$ & 0.642 & NS \\
\hline Body Mass Index & $24.1(2.8)$ & $23.3(2.6)$ & 0.139 & \\
\hline
\end{tabular}

Table 3. Details of collected oocyte characteristics (NS: Non-Significant)

\begin{tabular}{|l|c|c|c|c|}
\hline Characteristic & G1 With Cumulus & G2 Without Cumulus & P Value & Significance \\
\hline Number of Patients & 67 & 66 & & \\
\hline Mean (SD) No. of Retrieved M2 & $9.3(3.9)$ & $9.1(3.7)$ & 0.845 & NS \\
$\begin{array}{l}\text { Oocytes per patient } \\
\text { [Mean (SD)] }\end{array}$ & $86.4 \%$ & $85.8 \%$ & & \\
\hline $\begin{array}{l}\text { No. total retrieved M2 oocytes } \\
\text { No. total retrieved oocytes }\end{array}$ & $(624 / 722)$ & $(602 / 701)$ & & \\
\hline
\end{tabular}


Table 4. Comparison of embryo development and pregnancy properties of G1 and G2

\begin{tabular}{|l|c|c|c|c|}
\hline Characteristic & $\begin{array}{c}\text { G1 With Cumulus } \\
\text { [Mean (SD)] }\end{array}$ & $\begin{array}{c}\text { G2 Without Cumulus } \\
\text { [Mean (SD)] }\end{array}$ & significance \\
\hline Number of Patients & 67 & 66 & 0.681 & 0.03 \\
\hline Fertilization rate [Mean (SD)] & $78.2(19.1)$ & $79.5(7.3)$ & 0.03 & NS \\
\hline Percent of high quality embryos & $35.3(14.8)$ & $27.6(14.5)$ & 0.281 & S \\
\hline Number of high quality embryos & $3.1(1.4)$ & $2.4(1.1)$ & 0.268 & NS \\
\hline No. of embryos transferred & $2.4(0.6)$ & $2.3(0.5)$ & 0.028 & S \\
\hline Day of embryo transfer & $3.2(0.8)$ & $3.4(0.8)$ & & S \\
\hline Implantation & $36(53.7 \%)$ & $23(34.8 \%)$ & & \\
\hline $\begin{array}{l}\text { Ultrasound confirmation } \\
\text { of gestational sac }\end{array}$ & $30(44.7 \%)$ & $3(27.2 \%)$ & & \\
\hline Twin Pregnancy & 3 & 3 & & \\
\hline Triplet Pregnancy & 1 & & \\
\hline S: Significant, NS: Non-Significant & & &
\end{tabular}

Table 5. Main components of the ECM of CCOC (6-9)

\begin{tabular}{|l|}
\hline hyaluronan \\
\hline proteoglycans \\
\hline serum-derived hyaluronan-associated proteins \\
\hline heparan sulphate \\
\hline condroitin sulphate \\
\hline inter- $\alpha$-trypsin inhibitor \\
\hline cumulus matrix \\
\hline hyladerin \\
\hline fibronectin \\
\hline tenascin-c \\
\hline laminin \\
\hline Serum-derived HA-associated protein \\
\hline collagen IV \\
\hline versican \\
\hline TSG-6 \\
\hline PTX-3 \\
\hline PTX-3: pentraxin-3; TSG-6: TNF- $\alpha$-stimulated gene/protein 6; \\
HA: hyaluronic acid \\
\hline
\end{tabular}

There were no differences between the groups concerning fertilization rates of 78.2 (19.1) and 79.5 (17.3) of group 1 (G1) and group 2 (G2), respectively.

The percent values of high quality embryos were $35.3 \% \pm 14.8 \%$ and $27.6 \% \pm 14.5 \%$ for the cumulus co-cultured and without cumulus cultured groups, respectively. There were significant differences $(p=0.03)$ between groups with regard to high quality embryo development. The numbers of high quality embryos were also significantly different between the 2 groups, with $3.1 \pm 1.4$ and $2.4 \pm 1.1$ embryos in the study and control groups, respectively $(\mathrm{p}=0.03)$.

The number of transferred embryos and transfer dates showed similar properties in both groups. Statistically, the biochemi- cal implantation and ongoing pregnancy rates confirmed by positive cardiac activity via ultrasound were significantly different $(\mathrm{p}=0.028$ and $\mathrm{p}=0.047$, respectively) in the 2 groups. Implantation rates in study and control groups were $53.7 \%$ and $34.8 \%$, respectively. Ongoing pregnancy rates based on cardiac ultrasound confirmation were $44.7 \%$ and $27.2 \%$ in the study and control groups, respectively. There were 3 sets of twins in each of the 2 groups, while 1 triplet pregnancy occurred in the study group. Our results are described in Table 4.

\section{Discussion}

The present study showed that the co-culture of embryos with ICM results in a higher percent of high quality embryos. Furthermore, transfer of the co-cultured embryo to the uterus with ICM results in a significant increase in the implantation and pregnancy rates. The present technique does not involve additional effort during oocyte manipulation, and only adds 45-90 seconds to the procedure for the cutting of cumulus bodies. A higher pregnancy rate can be achieved with no extra cost to the patient.

Our preliminary study (5), in which the properties of embryos generated with and without CCOC were evaluated in 100 infertile couples (50 in the study group and 50 controls), revealed positive results with regard to embryo development and ongoing pregnancy rates (36\% for the control group and $46 \%$ for the CCOC-added group), when cumulus cells were added to the culture environment. In this initial study, cumulus cell addition was not introduced during the ET procedure. The results of this preliminary study stimulate further research aimed at assessing the effects of cumulus co-culture and developing improved techniques.

During the natural development of the embryo and fertilization in the oviduct, the oocyte is surrounded with cumulus cells and a special ECM composed mainly of hyaluronan, cross-linking proteins, and proteoglycans (6-9). A partial list of the components of the ECM of CCOCs is shown in Table 5. 
The interaction and close contact between the cumulus cells and developing oocyte are characterized by the presence of secreted factors (10). The interaction between the oocyte and surrounding cumulus cells is controlled by the oocyte, and this interaction ultimately determines oocyte quality (11), while the cumulus cells play a significant role in the protection of the developing embryo (12). In addition, there is a T cell population detected inside the cumulus cell mass which enhances embryo development (13). Considering that the effects of fertility treatments may not be exactly the same in natural and ovarian-stimulated cycles (14), the present study used subjects that had received hormone treatment for controlled ovarian stimulation.

Based on our observations, the relationship between the embryo and the ICM can take several forms:

- Embryos may be embedded in the ICM, and in this case, the embryos were detached from the cell culture dish and surrounded by cumulus cell layers and extracellular matrix, and a gel-like substance may surround the embryo;

- ICM may be dispersed and the cumulus cells might attach to the dish surface in a monolayer, with small cumulus cell clusters floating in the droplet, while the embryo remains in contact with the culture dish surface; or

- Embryos and ICM stay separated and are not in contact. Various intermediate forms between the above-described 3 situations were found, and while some droplets were clearly defined, others existed in an intermediate form.

Stereomicroscopic observations of the embryos embedded in the ICM showed that embryos were inside a gel-like mass. This gel-like substance was mainly composed of hyaluronan. A limited number of excess embryos (surplus embryos after transfer) embedded in ICM were stained with Toluidine blue (0.05\%), and some local polychromatic areas (light magenta) were observed in the extracellular environment (unpublished data).

One limitation of the present study was the visualization of embryos in the study group using stereo- and inverted microscopes due to the surrounding layer of cumulus cells, which raised the embryos above the surface of the dish, making focusing difficult and delaying the inspection of droplets.

Signalling interactions between the granulosa, cumulus cells, local extracellular matrix, and oocytes have been well documented in studies on humans, rat, mouse, bovine, and swine. In most of these studies, a genetic site for this interaction was revealed (15), and some of the benefits of this relationship were found to be due to the antioxidant effect of cumulus cells (12). There is a study in the literature (16) using cumulus cells for coculture and embryo transfer, but in their study they separated cumulus cells with hyaluronidase enzyme treatment and so used monolayer cultivation. In our study we gave special importance to avoiding enzyme contact with the cumulus mass, because cumulus cells with their intact extracellular matrix seem more physiological.

Signalling factors can activate or inhibit processes, and they can affect the expression of specific receptors at a certain time or due to the activation of a different process (17).
The specific definition of granulosa, cumulus, and oocyte interactions or mechanisms is beyond the scope of this study, and these parameters depend on the developing technology, which can change our understanding of these processes.

The results of the present study suggest that the development of a microinjection technique where cumulus cell layers are not removed may result in the improvement of the applications of assisted-reproduction techniques.

\section{Conflict of interest}

No conflict of interest was declared by the authors.

\section{References}

1. Satterfield MC, Song G, Kochan KJ, Riggs PK, Simmons RM, Elsik $\mathrm{CG}$, et al. Discovery of candidate genes and pathways in the endometrium regulating ovine blastocyst growth and conceptus elongation. Physiol Genomics 2009; 39: 85-99. [CrossRef]

2. Bazer FW, Wu G, Spencer TE, Johnson GA, Burghardt RC, Bayless $\mathrm{K}$. Novel pathways for implantation and establishment and maintenance of pregnancy in mammals. Mol Hum Reprod 2010; 16: 135-52. [CrossRef]

3. Gorkemli H, Ak D, Akyurek C, Aktan M, Duman S. Comparison of pregnancy outcomes of progesterone or progesterone + estradiol for luteal phase support in ICSI-ET cycles. Gynecol Obstet Invest 2004; 58: 140-4. [CrossRef]

4. Veeck L. Oocyte assessment and biological performance. Ann N Y Acad Sci. 1988; 541: 259-74. [CrossRef]

5. Cihangir N, Görkemli H, Özdemir S, Aktan M, Duman S. Influence of cumulus cell coculture and cumulus aided embryo transfer on embryonic development and pregnancy rates. J Turkish -German Gynecol Assoc. 2010; 11: 121-6.

6. Russell DL, Salustri A. Extracellular matrix of the cumulus-oocyte complex. Semin Reprod Med 2006; 24: 217-27. [CrossRef]

7. Zhuo L, Kimata K. Cumulus oophorus extracellular matrix: its construction and regulation. Cell Struct Funct 2001; 26: 189-96. [CrossRef]

8. Richards JS. Ovulation: New factors that prepare the oocyte for fertilization. Mol Cell Endocrinol 2005; 234: 75-9. [CrossRef]

9. Relucenti M, Heyn R, Correr S, Familiari G. Cumulus oophorus extracellular matrix in the human oocyte: a role for adhesive proteins. It J Anat Embryol 2005; 110: 219-24.

10. Makabe S, Naguro T, Stallone T. Oocyte-follicule interactions during ovarian follicle development, as seen by high resolution scanning and transmission microscopy in humans. Microsc Res Tech 2006; 69: 436-49. [CrossRef]

11. Gilchrist RB, Lane M, Thompson JG. Oocyte-secreted factors: regulators of cumulus cell function and oocyte quality. Hum Reprod Update 2008; 14: 159-77. [CrossRef]

12. Van Blerkom J, Davis P, Thalhammer V. Regulation of mitochondrial polarity in mouse and human oocytes: the influence of cumulus derived nitric oxide. Mol Hum Reprod 2008; 14: 431-44. [CrossRef]

13. Piccinni MP. Role of T-Cell cytokines in decidua and in cumulus oophorus during pregnancy. Gynecol Obstet Invest 2007; 64: 144-8. [CrossRef]

14. Liu Y, Kodithuwakku SP, Ng PY, Chai J, Ng EH. Excessive ovarian stimulation up-regulates the Wnt-signaling molecule DKK1 in human endometrium and may affect implantation: an in vitro coculture study. Hum Reprod 2010; 25: 479-90. [CrossRef] 
15. Adriaenssens T, Wathlet S, Segers I, Verheyen G, De Vos A, Van der Elst $\mathrm{J}$, et al. Cumulus cell gene expression is associated with oocyte developmental quality and influenced by patient and treatment characteristics. Hum Reprod 2010; 25: 1259-70. [CrossRef]

16. Parikh FR,Nadkarni SG,Naik NJ,Naik DJ, Uttamchandani SA. Cumulus coculture and cumulus aided embryo transfer increases pregnancy rates in patients undergoing in vitro fertilization. Fertil Steril 2006; 86: 839-47 [CrossRef]

17. Sugiura K, Su YQ, Li Q, Wigglesworth K, Matzuk MM, Eppig JJ. Fibroblast growth factors and epidermal growth factor cooperate with oocyte-derived members of the TGFbeta superfamily to regulate Spry2 mRNA levels in mouse cumulus cells. Biol Reprod 2009; 81: 833-41. [CrossRef] 